Poverty and Agrarian Distress in Orissa

Srijit Mishra

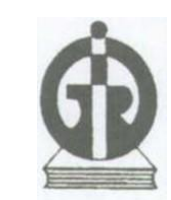

Indira Gandhi Institute of Development Research, Mumbai

September 2009

http://www.igidr.ac.in/pdf/publication/WP-2009-006.pdf 


\title{
Poverty and Agrarian Distress in Orissa ${ }^{1}$
}

\author{
Srijit Mishra \\ Indira Gandhi Institute of Development Research (IGIDR) \\ General Arun Kumar Vaidya Marg \\ Goregaon (E), Mumbai- 400065, INDIA \\ Email: srijit@igidr.ac.in
}

\begin{abstract}
The relatively lower reduction of poverty in Orissa, 0.2 percentage points per annum from 48.6\% in 1993-94 to 46.4\% in 2004-05, has been a matter of concern. The current exercise attempts to analyse whether part of the explanation lies in the state of affairs in agriculture. An analysis for 2004-05 shows that incidence of poverty is 47\% for rural and 44\% for urban Orissa. The vulnerable sub-groups are southern (73\% rural, 55\% urban) and northern (59\% rural, $43 \%$ urban) across National Sample Survey (NSS) regions, the scheduled tribes (76\% rural, $65 \%$ urban) and scheduled castes (50\% rural, $75 \%$ urban) across social groups, the agricultural labourers (65\%) and other labourers (52\%) in rural areas and casual labourers $(56 \%)$ in urban areas across household type, and marginal and small farmers (51\%) across size-class of land possessed in rural areas. What is even worrying is a much greater incidence of calorie poor (79\% rural and 49\% urban). This reflects a gap in the poverty line and the calorie that it is supposed to represent and a seeming nutritional crisis even among the groups that resorts to hard labour that includes among others marginal and small farmers and landless households - the hands that grow food. The agrarian scenario is in dire straits. Per capita per day returns from cultivation, based on the situation assessment survey of 2002-03, is less than four rupees, a pittance. What is more, in 1990s, agricultural value addition and growth in production has been negative across all crop groups and paddy production, the main crop, shows a decline in all districts. It is this poor showing in agriculture that does partly explain the slow reductions of poverty in the 1990s in Orissa. The call of the hour is people-centric planning that revives the livelihood bases of the farmers and agricultural labourers.
\end{abstract}

Key words: Calorie poor, Incidence of poor, Agricultural growth

JEL Codes: I32, O13, O15, Q10,

\footnotetext{
${ }^{1}$ Comments from G.S. Bhalla, Sarthak Gaurav, R. Radhakrishna, V.M. Rao, D.N. Reddy and S.L. Shetty to earlier versions (particularly, Mishra, 2007b) were helpful. Usual disclaimers apply.
} 


\title{
Poverty and Agrarian Distress in Orissa
}

\author{
Srijit Mishra
}

\section{Introduction}

Orissa has been among the poorest states in the country. In 2004-05, the headcount ratio of people below the poverty line is $46 \%$ compared to $28 \%$ for all India. What is more, in recent years (1993-94 to 2004-05) the decline in poverty has been as low as 0.2 percentage points per annum. The current exercise is an attempt to analyse whether part of the explanation lies in the happenings in agriculture.

Orissa constitutes about $4.9 \%$ of India's total area and 3.6\% of total population as per 2001 census - its density of population at 236 per square kilometre is lower than India's 324 . In current prices, the per capita net state domestic product at Rs.22,630/- in 2007-08 is $68 \%$ of India's per capita net national product. Compared to all India average, the share of agriculture in gross state domestic product is relatively greater (25\% to 19\%, 2005-06), share of forest area to total area is greater ( $37 \%$ to $22 \%, 2002-03)$, net sown area to total reported area is lower $(37 \%$ to $44 \%, 2002-03)$, net area irrigated to net sown area is lower (23\% to $40 \%$, 2002-03), fertilizer consumption is lower than half (2004-05) and yield of rice is less than three-fourths (2003-04) of the all India average (Government of Orissa (GOO), 2008). Workforce composition of 2001 suggests that $65 \%$ are dependent on agriculture (30\% cultivators and 35\% agricultural labourers) whereas it is 58\% for all India. Getting back to the problem, section 2 elaborates on the poverty scenario, section 3 discusses the agrarian scenario and section 4 gives some concluding remarks.

\section{Poverty Scenario in Orissa}

The proportion of poor in Orissa has always remained higher than the national average (Table 1). There was not much decline in the 1970s. The decline gained momentum in the 1980s, but for urban poverty, which has increased during the latter part. What is more, the decline seems to be negligible in the 1990s. It declined by less then 0.3 percentage points per annum for rural Orissa and increased for urban Orissa. 


\begin{tabular}{|c|c|c|c|c|c|c|}
\hline \multicolumn{7}{|c|}{$\begin{array}{c}\text { Table 1 } \\
\text { Incidence of Poverty in Orissa and India, 1973-74 to 2004-05 }\end{array}$} \\
\hline \multirow[t]{2}{*}{ Year } & \multicolumn{3}{|c|}{ Orissa } & \multicolumn{3}{|c|}{ India } \\
\hline & Rural & Urban & Combined & Rural & Urban & Combined \\
\hline 1973-74 & 67.28 & 55.62 & 66.18 & 56.44 & 49.01 & 54.88 \\
\hline $1977-78$ & 72.38 & 50.92 & 70.07 & 53.07 & 45.24 & 51.22 \\
\hline 1983 & 67.53 & 49.15 & 65.29 & 45.65 & 40.79 & 44.48 \\
\hline $1987-88$ & 57.64 & 41.53 & 55.58 & 39.09 & 38.20 & 38.85 \\
\hline 1993-94 & 49.72 & 41.64 & 48.56 & 37.27 & 32.36 & 35.97 \\
\hline 2004-05 & 46.80 & 44.30 & 46.40 & 28.30 & 25.70 & 27.50 \\
\hline
\end{tabular}

\begin{tabular}{|c|c|c|c|c|c|c|c|c|c|c|c|}
\hline \multicolumn{12}{|c|}{$\begin{array}{c}\text { Table } 2 \\
\text { Incidence of Poor and Calorie Poor across Sub-groups in Orissa, 2004-05 }\end{array}$} \\
\hline \multirow{3}{*}{\multicolumn{2}{|c|}{ Sub-group }} & \multicolumn{5}{|c|}{ Rural } & \multicolumn{5}{|c|}{ Urban } \\
\hline & & \multicolumn{2}{|c|}{\begin{tabular}{c|} 
Head Count \\
Ratio
\end{tabular}} & \multicolumn{3}{|c|}{ Share } & \multicolumn{2}{|c|}{\begin{tabular}{c|c} 
Head Count \\
Ratio
\end{tabular}} & \multicolumn{3}{|c|}{ Share } \\
\hline & & $\begin{array}{r}\text { Poor } \\
(\%)\end{array}$ & $\begin{array}{r}\text { Cal- } \\
\text { orie } \\
\text { Poor } \\
(\%) \\
\end{array}$ & \begin{tabular}{|r|} 
Popu- \\
lation \\
$(\%)$
\end{tabular} & \begin{tabular}{r|} 
Poor \\
$(\%)$
\end{tabular} & 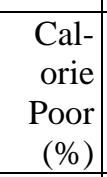 & $\begin{array}{r}\text { Poor } \\
(\%)\end{array}$ & $\begin{array}{r}\text { Cal- } \\
\text { orie } \\
\text { Poor } \\
(\%) \\
\end{array}$ & $\begin{array}{r}\text { Popu- } \\
\text { lation } \\
(\%)\end{array}$ & $\begin{array}{r}\text { Poor } \\
(\%)\end{array}$ & $\begin{array}{r}\text { Kal } \\
\text { Poor } \\
(\%)\end{array}$ \\
\hline \multirow[t]{3}{*}{ NSS Region } & Coastal & 27.4 & 64.6 & 46.4 & 27.1 & 40.1 & 44.1 & 40.5 & 49.8 & 49.1 & 40.9 \\
\hline & Sout & 72.7 & 91.5 & 18.6 & 28.9 & 22.8 & 55.0 & 64.4 & 10.0 & 12.4 & \\
\hline & North & 59.1 & 79.1 & 35.0 & 44.0 & 37.0 & 42.9 & 56.5 & 40.1 & 38.5 & 46.0 \\
\hline \multirow{4}{*}{$\begin{array}{l}\text { Social } \\
\text { Group }\end{array}$} & Scheduled Tribe & 75.8 & 89.1 & 25.6 & 41.5 & 30.6 & 64.6 & 57.3 & 9.0 & 13.0 & 10.4 \\
\hline & Scheduled Caste & 49.9 & 73.5 & 17.6 & 18.7 & 17.3 & 74.5 & 60.8 & 13.7 & 22.8 & 16.9 \\
\hline & Other Backward C & 37.1 & 69.9 & 39.4 & 31.1 & 36.9 & 48.6 & 49.2 & 30.5 & 33.2 & 30.5 \\
\hline & Others & 23.5 & 65.3 & 17.3 & 8.7 & 15.2 & 29.7 & 44.5 & 46.8 & 31.0 & 42 \\
\hline \multirow{5}{*}{$\begin{array}{l}\text { Household } \\
\text { Type } \\
\text { (HHT) }\end{array}$} & $\mathrm{HHT}$ & 32 & 68.1 & 19.0 & 13.3 & 17.3 & 50.2 & 50.4 & 45.1 & 50.7 & 46 \\
\hline & \begin{tabular}{|l|} 
HHT2 \\
\end{tabular} & Ju & 82.2 & 28.0 & 38.6 & 30.9 & 20.9 & 45.5 & 34.3 & 16.1 & 31 \\
\hline & HHT3 & 52.0 & 84.1 & 10.4 & 11.5 & 11.7 & 89.3 & 56.3 & 15.0 & 30.0 & 17.1 \\
\hline & HHT4 & 46.1 & 72.6 & 33.2 & 32.7 & 32.3 & $\mathrm{NA}$ & NA & NA & NA & $\mathrm{NA}$ \\
\hline & HHT9 & 19.8 & 62.4 & 9.3 & 3.9 & 7.8 & 26.4 & 44.2 & 5.5 & 3.3 & 4.9 \\
\hline \multirow{6}{*}{$\begin{array}{l}\text { Size-class } \\
\text { Of Land } \\
\text { Possessed }\end{array}$} & Landless, $0-0.1$ ha & 41.8 & 74.2 & 35.9 & 31.7 & 35.4 & $\mathrm{NA}$ & NA & NA & NA & $\mathrm{NA}$ \\
\hline & Marginal, 0.1-1 ha & 50.8 & 75.8 & 37.5 & 40.7 & 38.1 & NA & NA & NA & NA & NA \\
\hline & Small, 1-2 ha & 51.4 & 76.6 & 19.3 & 21.2 & 19.6 & $\mathrm{NA}$ & NA & NA & NA & $\mathrm{NA}$ \\
\hline & Semi-Medium, 2-4 & 42.6 & 69.0 & 5.5 & 5.0 & 5.1 & $\mathrm{NA}$ & NA & NA & NA & NA \\
\hline & Medium, 4-10, ha & 36.9 & 71.9 & 1.7 & 1.4 & 1.7 & NA & NA & NA & NA & NA \\
\hline & Large, $10+$ & 12.6 & 76.4 & 0.1 & 0.0 & 0.1 & $\mathrm{NA}$ & NA & NA & NA & NA \\
\hline Orissa & State & 46.9 & 74.7 & 100.0 & 100.0 & 100.0 & 44.7 & 49.3 & 100.0 & 100.0 & 100.0 \\
\hline \multicolumn{12}{|c|}{$\begin{array}{l}\text { Note: Poor refers to Monthly Per Capita Expenditure (MPCE) below the poverty line provided by the Planning } \\
\text { Commission and calorie poor refers to those below } 2400 \text { per capita in rural areas and } 2100 \text { per capita in urban } \\
\text { areas. NSS denotes National Sample Survey. In rural areas, household type (HHT) } 1 \text { through } 4 \text { and } 9 \text { denote } \\
\text { Self-employed in non-agriculture, Agricultural labour, Other labour, Self-employed in agriculture and Others } \\
\text { respectively; in urban areas, household type } 1 \text { through } 3 \text { and } 9 \text { denote Self-employed, Wage earnings/Salaried, } \\
\text { Casual labour, and Others respectively. NA denotes not applicable. } \\
\text { Source: Calculated from unit level data. }\end{array}$} \\
\hline
\end{tabular}


The high incidence of poor among scheduled tribes and scheduled castes and in southern and northern regions are matters of concern. Understandably, agricultural and other labourers in rural Orissa and casual labourers in urban Orissa have a greater incidence of poverty. What is worrying is incidence of $46 \%$ for poor among those self-employed in agriculture. Those selfemployed in non-agriculture also have a greater incidence than the all India average and for urban Orissa the self-employed have a greater incidence than the state average.

Incidence of poor by size-class of land indicates a greater burden among marginal and small farmers. A relative higher proportion of the landless could be having non-agricultural sources of income. As expected, incidences in expenditure poor are lower for medium and large farmers, but their proportions in the population are very less indicating that Orissa's rural households largely consist of marginal and small farmers (57\%) and landless (36\%).

For all sub-groups in rural Orissa and some sub-groups in urban Orissa, the incidence of calorie poor is much higher. On the one hand, this indicates that the Planning Commission poverty line does not represent the calorie norm it is supposed to. On the other hand, even after discounting for a reduced calorie norm for those whose nature of work is sedentary in nature, the seemingly high calorie deficiency among the sub-groups known to put in hard labour points to a nutritional crisis. It is worrying that these groups also happen to be marginal and small farmers and agricultural labourers who produce food. Now, let us look up the agrarian scenario in Orissa.

\section{Agrarian Scenario in Orissa}

Distribution of operational holdings from 1990-91 to 2000-01 indicate that the total number of operational holdings has been increasing over the years, but the area under operation has been declining (Table 3). The share of number of marginal holdings as well as the share of area under marginal holdings has been increasing, explaining the decline in inequality. 


\begin{tabular}{|c|c|c|c|c|}
\hline \multicolumn{5}{|c|}{$\begin{array}{c}\text { Table 3 } \\
\text { Distribution of Operational Holdings in Orissa, 1990-91 to 2000-01 }\end{array}$} \\
\hline \multirow{2}{*}{ Size-class } & \multicolumn{2}{|c|}{ 1990-91 } & \multicolumn{2}{|c|}{$2000-02$} \\
\hline & $\begin{array}{l}\text { Operational } \\
\text { holdings (\%) }\end{array}$ & Area (\%) & $\begin{array}{c}\text { Operational } \\
\text { holdings }(\%)\end{array}$ & Area $(\%)$ \\
\hline Marginal & 53.6 & 19.7 & 56.4 & 22.7 \\
\hline Small & 26.2 & 26.9 & 27.4 & 30.4 \\
\hline Semi-medium & 15.2 & 29.5 & 12.3 & 26.5 \\
\hline Medium & 4.7 & 19.1 & 3.6 & 16.1 \\
\hline Large & 0.4 & 4.8 & 0.3 & 4.3 \\
\hline Total & 100.0 & 100.0 & 100.0 & 100.0 \\
\hline Total value* & 39.48 & 52.96 & 40.67 & 50.81 \\
\hline Gini & \multicolumn{2}{|c|}{0.4456} & \multicolumn{2}{|c|}{0.4318} \\
\hline $\begin{array}{l}\text { Note: * Total } \\
\text { operation. } \\
\text { Source: GOO }\end{array}$ & $\begin{array}{l}\text { ustat.com (acc of } \\
\text { asta }\end{array}$ & $\begin{array}{l}\text { al holdings a } \\
25 \text { May } 2007\end{array}$ & in ' 000 hec & area under \\
\hline
\end{tabular}

\begin{tabular}{|l|r|r|}
\hline \multicolumn{3}{|c|}{ Table 4 } \\
Incremental Value of Output in Agriculture and \\
its Share over Crop Groups, Orissa and India \\
(TE 2002-03 over TE 1992-93 in 1993-94 prices) \\
\hline Incremental value/Share & \multicolumn{1}{|c|}{ Orissa } & \multicolumn{1}{c|}{ India } \\
\hline Incremental Value, Rs Lakh & -67335 & 4124466 \\
\hline Cereals & -70.6 & 22.1 \\
\hline Pulses & -65.9 & -1.6 \\
\hline Oil-seeds & -71.1 & -1.3 \\
\hline Fibers & -1.8 & -0.8 \\
\hline Sugar & -10.3 & 9.8 \\
\hline Fruits and vegetables & 131.5 & 57.8 \\
\hline Condiments and Spices & -4.6 & 7.2 \\
\hline Drugs and Narcotics & -3.3 & 4.5 \\
\hline By products & -6.6 & -0.2 \\
\hline Other Crops & 0.2 & 2.0 \\
\hline Kitchen garden & 2.5 & 0.5 \\
\hline Total & -100.0 & 100.0 \\
\hline $\begin{array}{l}\text { Note: Share is calculated over the absolute change in } \\
\text { incremental value. Negative/positive share would indicate } \\
\text { decrease/increase respectively. } \\
\text { Source: Mishra (2007a) }\end{array}$ & \multicolumn{2}{|l}{} \\
\hline
\end{tabular}

In 2002-03, calculation from the situation assessment survey gives average returns from cultivation per hectare in Orissa at Rs.3633/- in Kharif and Rs.5284 in Rabi (Mishra, 2007a). This is about $60 \%$ of the returns at the all India level. Being a drought year, the value of output in agriculture at constant 1993-94 prices was Rs.613,903 lakh in Orissa. This was lower than the previous year by $27 \%$ whereas at the all India level the decline was only $2 \%$. To account for this, if one doubles the returns from cultivation one still gets a per capita per day return of less than four rupees. 
Between triennium ending (TE) 1992-93 and TE 2002-03 the total incremental value of output in agriculture at constant 1993-94 prices decreased by Rs.67,335 lakh whereas at the all India level it increased by Rs.4,124,466 lakh (Table 4). In Orissa, the decline has been negative for crop groups except for fruits and vegetables, other crops and kitchen garden, that is, those that hardly have any presence under gross cropped area.

\begin{tabular}{|c|c|c|c|c|c|c|}
\hline \multicolumn{7}{|c|}{$\begin{array}{c}\text { Table } 5 \\
\text { Trend Growth Rate of Production, Area and Yield in Orissa, } \\
\text { 1980s and 1990s, }(\%)\end{array}$} \\
\hline \multirow[t]{2}{*}{ Crops } & \multicolumn{2}{|c|}{ Production } & \multicolumn{2}{|c|}{ Area } & \multicolumn{2}{|c|}{ Yield } \\
\hline & 1980s & 1990s & 1980s & 1990s & $1980 \mathrm{~s}$ & 1990s \\
\hline Total Foodgrains & $3.3 *$ & $-2.1 * \#$ & $0.5 *$ & $-1.2 * \#$ & $2.9 *$ & -1.0 * \# \\
\hline Total Cereals & $3.5 *$ & $-1.5 * \#$ & -0.1 & $-0.4 *$ & $3.6 *$ & $-1.1^{*} \#$ \\
\hline Rice & $4.4 *$ & $-1.4 * \#$ & $0.6 *$ & $-0.2 * \#$ & $3.8 *$ & $-1.2^{*} \#$ \\
\hline Pulses & $2.3 *$ & $-7.4 * \#$ & $1.8 *$ & $-3.5 * \#$ & 0.4 & $-4.0^{*} \#$ \\
\hline Total Oilseeds & $5.2 *$ & $-7.0 * \#$ & $3.6 *$ & $-4.7 * \#$ & $1.6 *$ & $-2.3^{*} \#$ \\
\hline Total Fibres & 0.6 & $-6.5 * \#$ & $-2.3 *$ & $2.1 * \#$ & $2.9 *$ & $-8.6^{*} \#$ \\
\hline \begin{tabular}{|l|} 
Sugarcane \\
\end{tabular} & 0.5 & $-5.6 * \#$ & $\begin{array}{l}-0.8 \\
y\end{array}$ & $-4.8 * \#$ & $1.4 *$ & $-0.9^{*} \quad \#$ \\
\hline Tobacco & -1.1 & $-9.4 *$ & $-3.0 *$ & $-9.7 *$ & 1.9 & 0.3 \\
\hline Onion & 0.8 & $-7.0 * \#$ & $0.9 *$ & $-9.2 * \#$ & -0.1 & 2.2 * \\
\hline \begin{tabular}{|l|} 
Potato \\
\end{tabular} & $5.4 *$ & $-3.9 * \#$ & $1.5 *$ & $-3.3 * \#$ & $3.9 *$ & $-0.6^{*} \quad \#$ \\
\hline Condiments & $3.9 *$ & -0.3 & $1.5 *$ & $-1.8 * \#$ & $2.4 *$ & $1.5^{*}$ \\
\hline \multicolumn{7}{|c|}{$\begin{array}{l}\text { Note: Growth rate has been calculated using linear trend growth rate, } \ln (\mathrm{Yt})=\mathrm{a}+\mathrm{bt}+\mathrm{et} ; \mathrm{t}=0, \ldots \mathrm{T} \\
\text { denotes time. 1980s denotes triennium ending (TE) } 1981-2 \text { to TE } 1992-93.1990 \mathrm{~s} \text { denote TE } 1993-94 \\
\text { to TE 2004-05. The years taken are used as benchmark for agricultural purposes in India. * indicates } \\
\text { that the growth rate for that period is significantly different from zero at } 95 \% \text { CI and \# indicates that } \\
\text { the growth rate between the two periods are significantly different at 95\% CI. } \\
\text { Source: Calculated from data given in GOO (2004a, 2004b and 2005). }\end{array}$} \\
\hline
\end{tabular}

The linear trend growth rates in production, area and yield between 1980s (Triennium ending, TE 1981-82 to TE 1992-93) and 1990s (TE 1993-94 to TE 2004-05) show that production growth rate is negative in almost all crops in the 1990s (Table 5). This can be attributed to declines in area as well as yield. Further, the change in absolute production of TE 2004-05 over TE 1993-94 in quantity terms is also negative for all crops (Table 6). Disaggregation shows that the area effect is negative for all crops excluding fibres, the yield effect is negative for all crops except onion and only interaction effect is positive for most crops, but their share is very low. 


\begin{tabular}{|c|c|c|c|c|c|c|}
\hline \multicolumn{7}{|c|}{$\begin{array}{l}\text { Area, Yield and Interaction effect of Change in Production, Orissa, } \\
\text { TE 2004-05 over TE 1993-94 }\end{array}$} \\
\hline Crops & $\begin{array}{c}\text { Prdn., } \\
\text { TE } \\
2004-05 \\
\text { ('000 } \\
\text { tonnes/ } \\
\text { bales) }\end{array}$ & $\begin{array}{c}\text { Change in } \\
\text { Prdn., TE } \\
\text { 2004-05 over } \\
\text { TE } 1993-94 \\
\text { ('000 tonnes/ } \\
\text { bales) }\end{array}$ & $\begin{array}{l}\text { Area } \\
\text { effect } \\
(\%)\end{array}$ & $\begin{array}{l}\text { Yield } \\
\text { effect } \\
(\%)\end{array}$ & $\begin{array}{l}\text { Inter- } \\
\text { action } \\
\text { effect } \\
(\%)\end{array}$ & $\begin{array}{l}\text { Total } \\
\text { effect } \\
(\%)\end{array}$ \\
\hline Total Foodgrains & 6456.6 & -1339.1 & -61.7 & -42.8 & 4.5 & -100.0 \\
\hline Cereals & 5888.0 & -807.2 & -34.0 & -68.8 & 2.8 & -100.0 \\
\hline Rice & 5505.0 & -716.7 & -17.9 & -83.8 & 1.7 & -11 \\
\hline Pulses & 568.6 & -531.9 & -54.5 & -61.8 & 16.3 & -100.0 \\
\hline Total Oilseeds & 449.5 & -376.1 & -74.3 & -38.9 & 13.2 & -100.0 \\
\hline Total Fibres & 296.6 & -290.0 & 20.0 & -109.2 & -10.8 & -100.0 \\
\hline Sugarcane & 1882.6 & -1077.1 & -89.3 & -15.8 & 5.1 & -100.0 \\
\hline Tobacco & 3.2 & -5.8 & -98.5 & -4.0 & 2.5 & -100.0 \\
\hline Onion & 163.7 & -163.3 & -118.4 & 45.0 & -26.6 & -100.0 \\
\hline Potato & 75.6 & -37.3 & -83.8 & -22.3 & 6.2 & -100.0 \\
\hline Condiment \& Spices & 192.8 & -11.6 & -245.9 & 169.4 & -23.5 & -100.0 \\
\hline \multicolumn{7}{|c|}{$\begin{array}{l}\text { Note: TE denotes triennium ending. Prdn. denotes production which is ' } 000 \text { tonnes for all crops, but for } \\
\text { Fibres where it is ' } 000 \text { bales. Area, yield and interaction effects have been calculated by taking the } \\
\text { absolute value of the change in production. Thus negative/positive value would indicate decrease/increase } \\
\text { respectively. } \\
\text { Source: Calculated from data given in GOO }(2004 \mathrm{a}, 2004 \mathrm{~b} \text { and } 2005) \text {. }\end{array}$} \\
\hline
\end{tabular}

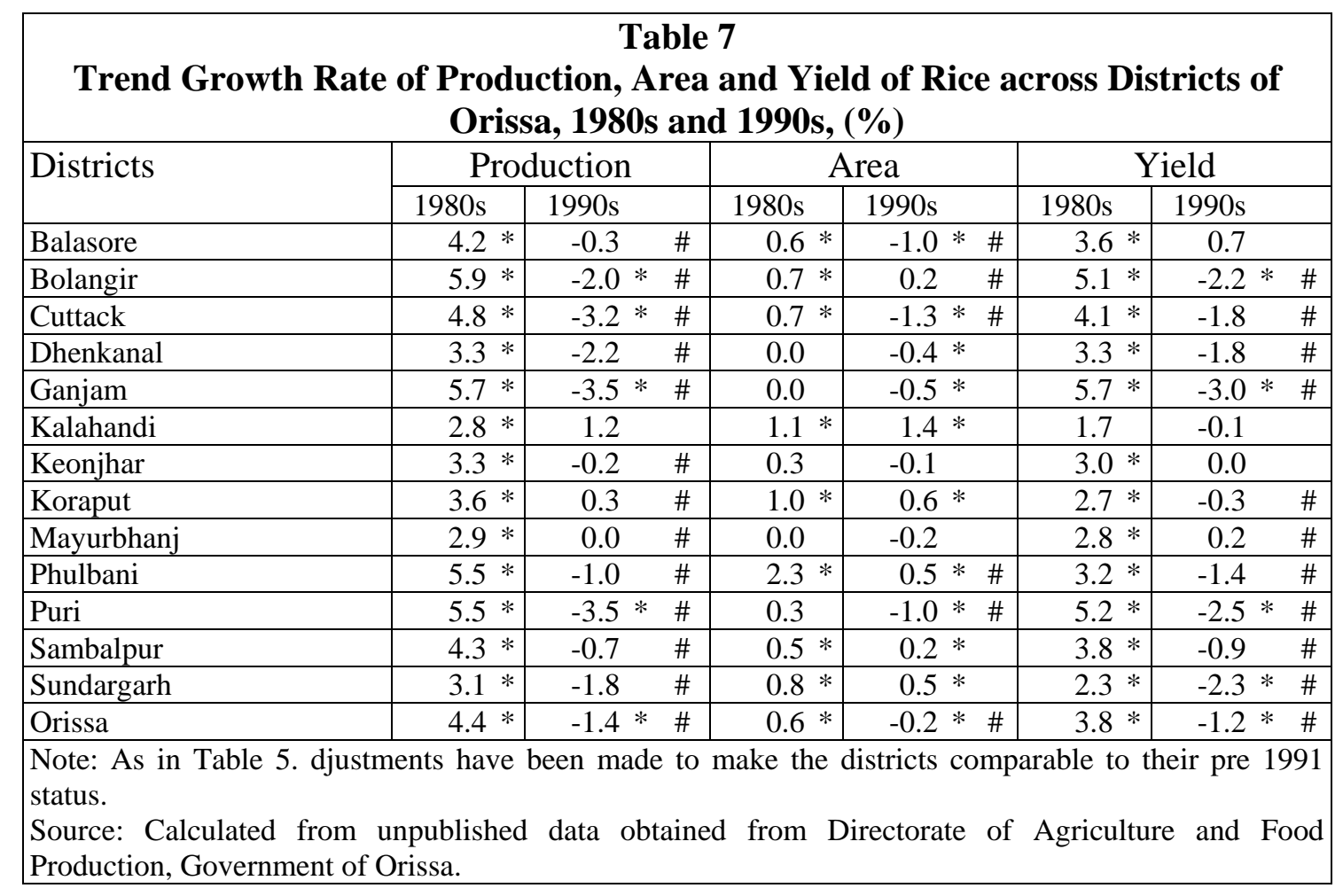


Trend growth rates of production, area and yield of rice for the 1980s and 1990s across districts of Orissa are negative in 10 of the 13 undivided districts (Table 7). More importantly, the growth rate in the 1990s is lower than 1980s in all the districts and this is statistically significant in 12 of the 13 districts. Growth of area in the 1990s is lower than 1980s in all the districts except for Kalahandi and the growth is negative in seven of the 13 districts as also for the state. Growth of yield rate is negative in 11 of the 13 districts and it is significantly lower to the 1980s in nine of these (Bolangir, Cuttack, Dhenkanal, Ganjam, Koraput, Phulbani, Puri, Sambalpur and Sundargarh) as also Mayurbhanj.

In 2004-05, the total irrigation potential created is about 39.3 lakh hectares (Kharif 26.65 lakh hectares and Rabi 12.66 lakh hectares), but only $68 \%$ of it was utilised (GOO, 2006). The important crops under irrigation are vegetables (43\%) paddy (39\%) and spices (22\%) during Kharif and paddy (100\%) sugarcane (100\%), other cereals (93\%), spices (69\%) and vegetables (64\%) among others during Rabi. Areas under pulses largely remain outside irrigation indicating that a drought can severely affect its production. Deficient rainfall will also have an adverse affect on irrigation in Rabi. One peculiar aspect of Orissa's agriculture is the regularity with which it has been affected by natural calamities - eight out of the ten years from 1996 to 2005 . This not only affects agricultural production but has huge burden on the exchequer and also has adverse implications on ongoing developmental activities.

The larger agrarian crisis need not always get manifested in increasing incidence of suicides, as is being witnessed in some other parts of the country (Reddy and Mishra, 2009). Nevertheless, the poor performance of agriculture on which a large proportion of population still depend and absence of non-farm opportunities does give some explanation to the relatively low reductions in poverty between 1993-94 and 2004-05.

\section{Concluding Remarks}

To sum up, Orissa is among the poorest states in India. What is worrying is that poverty reduction has not been impressive. Incidence of poverty indicates that it is high among scheduled groups and in the southern region. The latter comprises the undivided Kalahandi, Koraput and Phulbani districts that brings into mind the picture of starvation deaths, growing Naxalism and communal clashes. All these are independently important concerns, but their links with widespread poverty cannot be denied. One of the reasons, definitely, is the pitiable condition of agriculture in the state. Per capita per day returns from cultivation turn out to be 
less than four rupees, a pittance. What is more, agricultural value addition and growth in production has been negative across all crop groups. Paddy production shows decline in all districts. The regularity with which the state is exposed to natural calamities also needs further probing from the climate change perspective. Recent policy responses in doubling up of credit and debt waiver address only a symptom of the crisis. As a recent report indicates, the crisis has twin dimensions - one, that threatens the livelihood of the masses and another that indicates a failure of development planning (Government of India, 2007). These need to be addressed by taking into consideration the specificities of the local level factors. The call of the hour is people-centric planning that revives the livelihood bases of the farmers and agricultural labourers.

\section{References:}

Dev, S Mahendra, Manoj Panda and Kailas Sarap (2004) Poverty Reduction Strategies for Orissa, Report prepared for the Government of Orissa.

Government of India (2007), Report of the Expert Group on Agricultural Indebtedness, Ministry of Finance (Chairman: R. Radhakrishna).

Government of Orissa (GOO) (2004a) Agricultural Statistics of Orissa At A Glance, Directorate of Agriculture and Food Production.

GOO (2004b) Orissa Agricultural Statistics, 2003-04, Directorate of Agriculture and Food Production.

GOO (2005) Orissa Agricultural Statistics, 2004-05, Directorate of Agriculture and Food Production.

GOO (2006) A Profile on Agriculture in Orissa, 2006, Directorate of Agriculture and Food Production, Government of Orissa..

GOO (2007), Economic Survey 2006-07, Department of Economics and Statistics.

GOO (2008), Economic Survey 2007-08, Department of Economics and Statistics.

Mishra, Srijit (2007a) Agrarian Scenario in Post-reform India: A Story of Distress, Despair and Death, Working Paper No. WP-2007-001, Indira Gandhi Institute of Development Research, Mumbai.

Mishra, Srijit (2007b) Agriculture, Credit and Distress in Orissa, Paper submitted to Expert Group on Agricultural Indebtedness (Chairman R. Radhakrishna), Government of India.

Reddy, D. Narasimha and Srijit Mishra (eds.) (2009) Agrarian Crisis in India, Oxford University Press, New Delhi. 